\title{
Beak temperature change in response to acute stress in laying hens measured using infrared thermography
}

\author{
Maria Soroko ${ }^{1 *}$, and Daniel Zaborski² \\ ${ }^{1}$ Institute of Animal Breeding, Wroclaw University of Environmental and Life Sciences, Wroclaw, Poland \\ ${ }^{2}$ Department of Ruminants Science, West Pomeranian University of Technology, Szczecin, Poland
}

\begin{abstract}
SOROKO, M., D. ZABORSKI: Beak temperature change in response to acute stress in laying hens measured using infrared thermography. Vet. arhiv 91, 647-654, 2021.
\end{abstract}

\section{ABSTRACT}

The aim of this study was to investigate beak surface temperature changes to stress induced by fear resulting from tonic immobility using infrared thermography in laying hens. It was also examined whether beak temperatures differed among brown and white lines. The study was based on 89 hens from both lines: 45 White Leghorn birds and 44 Hy-Line brown birds. Beak temperature was measured with infrared thermography immediately before and after tonic immobility testing. The average temperature was obtained from the upper and lower beak area measurements. The beak temperature before tonic immobility had significantly higher temperature than after tonic immobility testing. Birds with shorter tonic immobility had lower temperature of beak than birds with longer tonic immobility. An interaction effect of stimulus (before and after tonic immobility) and tonic immobility time was significant. The upper and lower beak temperatures significantly $(\mathrm{P}<0.001)$ decreased in response to tonic immobility test in birds with shorter tonic immobility. Brown hens had higher lower-beak temperature compared to white hens. Based on these results, hens experienced tonic immobility resulting in beak surface temperature changes that were detectable using thermography. Therefore, infrared thermography could be used as a non-invasive technique to assess beak temperature changes in response to stress. Infrared thermography could improve ability to evaluate hens under potentially stressful conditions.

Key words: infrared thermography; beak temperature; tonic immobility; stress response; laying hen

\section{Introduction}

Applying reliable stress measurements in poultry is important for improving both animal welfare and production (MOBERG, 2000). Physiological homeostasis in poultry can be disturbed by various housing and environmental conditions. A variety of situations which birds are regularly exposed to have been classified as potential stressors. These include temperature/humidity, housing conditions, food form (EL-LETHEY, 2000), cage and floor pen management, social relationships, group size (CAMPO and DAVILA, 2002) as well as capture and handling procedures (KORTE et al., 1997).

\footnotetext{
*Corresponding author:

Maria Soroko, Institute of Animal Breeding, Wroclaw University of Environmental and Life Sciences, Chełmonskiego St. 38C, Wroclaw 51-630, Poland, Phone: +48 507495 109; Fax: +48 713205 785; E-mail: maria.soroko@upwr.edu.pl
} 
Plasma level of corticosterone has been used as indicator to assess physiological stress of poultry (GYIMOTHY, 2004). Drawing blood, however, is a stressor itself, and can lead to false peaks of corticosterone (BOISSY et al., 2007) and can be confused with fear reactions to humans (HEMSWORTH et al., 1994). Additionally, corticosterone levels are affected by the circadian rhythm, egg laying cycle (BEUVING and VONDER, 1981), and other factors, such as diet, environmental conditions and genetic factors (CHENG and MUIR, 2007). Consequently, research interests have focused on identifying and validating non-invasive methods of stress measurement that would greatly improve our ability to evaluate animals under potentially stressful conditions (FAIRHURST et al., 2013).

Previous studies indicated that acute physiological and physical stress triggers induced hyperthermia $(\mathrm{SIH})$, which correlates with other commonly used welfare indicators including increased glucocorticoids, heart rate, and behavioral fearfulness scores (EDGAR et al., 2013; HERBORN et al., 2015; MOE et al., 2017). Activation of SIH is characterized by a rapid drop in skin temperature and an increase in core body temperature, followed by an increase in body surface temperature (BRIESE et al., 1991). This thermoregulatory response has been measured using infrared thermography (IRT), a non-invasive technique that measures mid to longwave infrared radiation emanating from all objects and converts this to temperature (TATTERSALL, 2016; SOROKO et al. 2016). Previous studies found that surface temperature changes assessed with IRT are sensitive to handling procedures and represent a potentially useful tool for diagnosing the SIH response (EDGAR et al. 2013; HERBORN et al., 2015). IRT studies in chickens measured temperature changes in the head area, including the eye, bare face area, comb and wattle, which play important roles in thermoregulation. In response to handling procedure, there was an initial drop in eye and comb temperature followed by a temperature increase to levels significantly higher than baseline temperatures (EDGAR et al., 2013). Similarly, MOE et al. (2017) found that manual handling restraint in a vertical position led to increased head surface temperature. In another study, HERBORN et al. (2015) reported that temperature measurements of the comb and wattle were associated with the intensity of the stress response to a restraint stressor, indicating that stress can be quantified using skin temperature measurements.

There is increasing evidence for the beak, serving as a significant avenue of non-evaporative heat dissipation, to play a role in thermoregulation (SYMONDS and TATTERSALL, 2010); in various bird species (VAN DE VEN et al., 2016). The beak is extensively innervated and contains major cranial nerves like the trigeminal nerve that innervates the beak, part of the facial area, and associated mechanoreceptors, nociceptors and thermal receptors which require a supply of oxygenated blood (BREWARD and GENTLE, 1985). Therefore, blood vessels are prominent structures found in the beak where vessels regulate processes associated with vasoconstriction, vasodilation and thermoregulation (KUENZEL, 2007). At ambient temperatures of $20-25{ }^{\circ} \mathrm{C}$ vasodilation of the networks below the rhamphotheca (the sheath of keratin that forms the outer surface of the beak) causes an increase in beak surface temperature. This increased surface temperature effectively gives birds' beak a role of "thermal window" for controlling blood flow, just like birds' comb, wattle or legs (TATTERSALL, 2016). Previous studies have confirmed that eye and beak surface temperatures are related to core body temperatures (STEWART et al., 2008; WESCHENFELDER et al., 2012). However, there is little information in the scientific literature on investigating beak temperature as a possible noninvasive measure of acute stress in laying hens. A study conducted on broiler chickens found a correlation of beak with surface temperature and glucocorticoids, and concluded that beak surface temperature can indicate prolonged stress (WEIMER, 2017). Broiler chickens' physiological responses to stress cannot necessarily be extrapolated to laying hens, and stress levels can be related to bird genetic strain (DE HAAS et al., 2013). Differences in endocrine and behavioral variables have been observed between white and brown laying hens. FRAISSE 
and COCKREM (2006) reported that white birds have a higher stress response than brown birds.

Considering that IRT is a potential tool to measure the acute stress response in poultry, the present study aims to investigate beak surface temperature changes to stress induced by fear resulting from tonic immobility (TI). In addition, we examined whether beak temperatures differed among brown and white lines of laying hens.

\section{Materials and methods}

Animals and husbandry. All procedures were approved by the Institutional Animal Care and Use Committee of Purdue University.

This study was part of a larger study investigating the effects of probiotic supplementation on the behavior and welfare of laying hens. A total of 396 d-old Hy-Line W-36 White Leghorn and HyLine brown female chicks each were placed in two identical rooms and randomly distributed to 36 cages per room at the grower research unit of the Purdue University Poultry Research Farm. A total of 132 chickens were infrared beak trimmed at the hatchery on day 1 . Beak trimmed chickens were excluded from this study. The layer cage was equipped with a feeder, 2 nipple drinkers, 2 perches and a nesting area. The cage provides $1026 \mathrm{~cm}^{2}$ stocking density, $26.7 \mathrm{~cm}$ perch space/chicken, and $13.4 \mathrm{~cm}$ feeder space/chicken, respectively. The lighting schedule was gradually increased to 16light:8dard, which was achieved at 30 weeks of age.

Experimental procedures. This study was conducted on 89 randomly selected 40-wk-old hens from both lines: 45 White Leghorn birds and $44 \mathrm{Hy}$-Line brown birds. Before the trial, welfare assessments were conducted to examine feather condition, body weight, body condition, and foot health. All selected hens were clinically healthy and were in good physical condition.

TI was performed in a separate room, adjacent to where hens were housed, based on the method described by JONES and FAURE (1981). Each hen was placed on her back in a wooden cradle, with applying slight pressure on the hen's sternum and head for 15 seconds. A stopwatch was started to record latency for the bird to right itself. If the bird righted itself in less than 10 seconds, the restraining procedure was repeated. If TI was not induced after the second attempt, a different bird from the same cage was randomly selected for testing. The maximum duration of TI allowed was 15 minutes.

Temperature measurement. Thermographic images were captured of the left and right side of the hen's head using a VarioCAM hr Resolution infrared camera (uncooled microbolometer focal plane array, focal plane sensor array: $640 \times 480$ pixels, spectral range $7.5-14 \mu \mathrm{m}$, accuracy $\pm 1{ }^{\circ} \mathrm{C}$, sensitivity $0.02{ }^{\circ} \mathrm{C}$, InfraTec Dresden, Germany). Each bird had thermographic images taken at 2 time points: immediately before and just after TI. The first thermographic examination was taken just after taking the hen from her original cage and moving her to the hallway, out of auditory contact with other hens. Each bird was held in a cradle hold, with the person holding the bird using both hands. Images of the left and right side of the head including the beak, were taken at a distance of 0.3 $\mathrm{m}$ from the photographer. The emissivity was set for all readings at 9.7 at an angle of $90^{\circ}$ to the head (Fig.1). The second thermographic examination of each hen's head was taken immediately after the TI test in the examination room, after which the bird was returned to her original cage, with the entire process of handling and thermographic examination taking less than one minute. The ambient temperature in the examination room was maintained at $20^{\circ} \mathrm{C}$ and humidity at $70 \%$.

Thermal image analysis. Temperatures were obtained from the thermal images using the software package IRBIS 3 Professional software (InfraTec, Dresden, Germany). On each thermographic image of the hen's left and right side of the head, the average temperature was obtained from the lines drawn along the upper (XL1) and lower (XL2) beak. Both measurement lines were drawn from the cranial part of the beak down to the caudal part, to the area just behind the nasal opening (beak measurement between the caudal part of nasal opening and rictus was not included in order to avoid the mistake of skin measurement).

Statistical analysis. The statistical analyses were carried out separately for the lower and upper beak. 


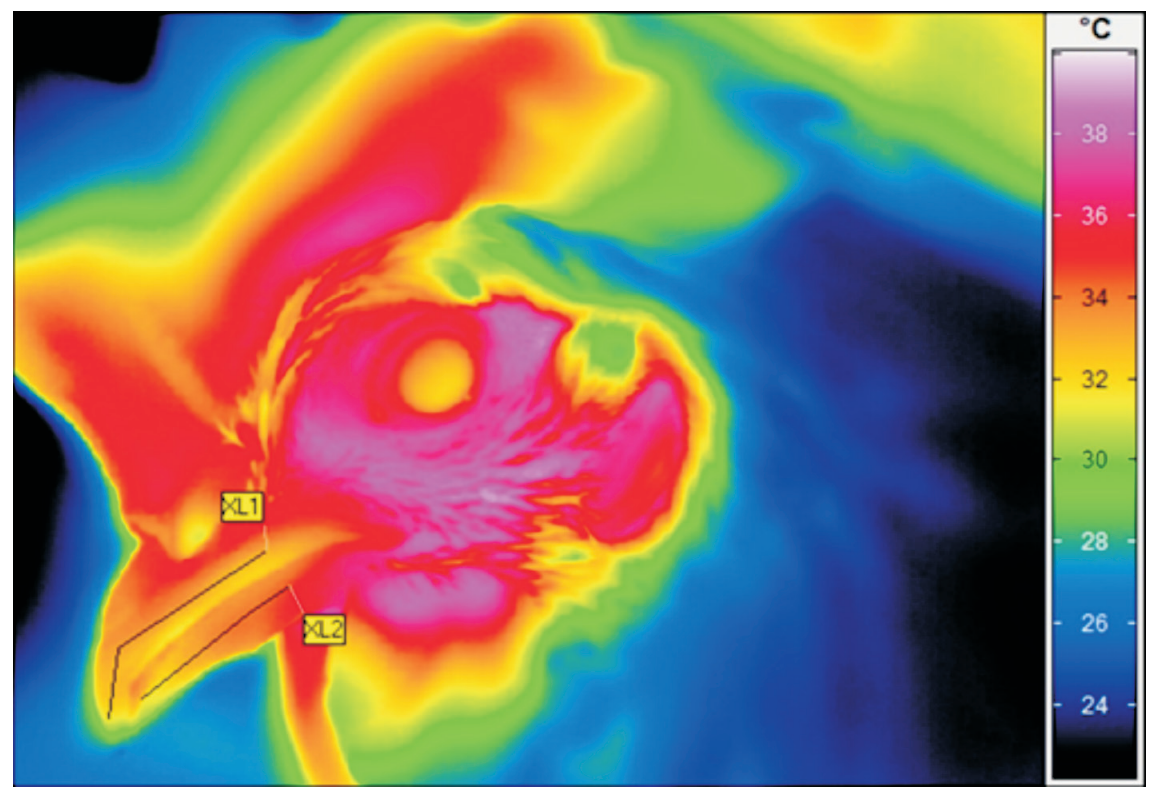

Fig. 1. Thermographic image of the left side of the hen's head taken before tonic immobility test. Measured average temperature from the upper beak (XL1) and the lower beak (XL2).

The beak's temperature measurement was compared before and after TI (stimulus), which was treated as a within-subject factor in the model; genetic line (brown $v s$ white) was a between-subject factor and TI duration (expressed in seconds) was a covariate.

The analysis in an ANOVA mixed model including a covariate was performed as a preliminary one. The influence of covariate was tested. It was statistically significant in interaction with stimulus, $\mathrm{F}(1,88)=18.47, \mathrm{P}<0.001, \eta^{2}=0.14$ as well as independent predictor of beak temperature, $\mathrm{F}(1$, $88)=10.98, \mathrm{P}<0.001, \eta^{2}=0.10$ for the lower beak. Analogous results were obtained for the upper beak $\left[\mathrm{F}(1,88)=12.04, \mathrm{P}<0.001, \eta^{2}=0.09\right.$ and $\mathrm{F}(1,88)$ $=13.58, \mathrm{P}<0.001, \eta^{2}=0.13$, respectively]. In order to interpret these interactions, an attempt was made to divide the continuous covariate variable in the model and convert it to the form of a categorical variable. Another object of the modification was an attempt to obtain information about the highest interaction between predictors. Finally, a threeway ANOVA model was used, which included the following factors: within-subject stimulus (before stress $v s$ after stress), between-subject immobility time based on its median value (shorter - below 329 s $v s$ longer - above 329 s) and genetic line (brown vs white).
The Mauchly's variance sphericity test (homogeneity of covariance) for the stimulus factor was not calculated, due to only two measurements (before stress $v s$ after stress), which were identical with the total sphericity; therefore, assumed sphericity statistics were presented (FIELD, 2009). Calculations for within subject effects were used. Statistical analysis was performed with Statistica 13 software (Tibco Inc., Tulsa, OK, USA).

\section{Results}

For the lower beak, the mean temperature before TI (32.07) was significantly higher $(\mathrm{P}=0.002)$ than that after TI (31.19). Also, birds with shorter TI had a significantly lower $(\mathrm{P}=0.005)$ mean beak temperature (30.99) than those with longer TI (32.26). Moreover, brown hens had a significantly higher $(\mathrm{P}=0.006)$ mean beak temperature (31.78) than did white hens (31.49). The interaction between stimulus and TI time was also statistically significant $(\mathrm{P}=0.003)$. In the case of a shorter TI time, the mean temperature of the lower beak was significantly higher $(\mathrm{P}<0.001)$ before TI $(31.70)$ than after TI (30.28). Such differences were not found for hens that had a longer TI time (Fig. 2). 


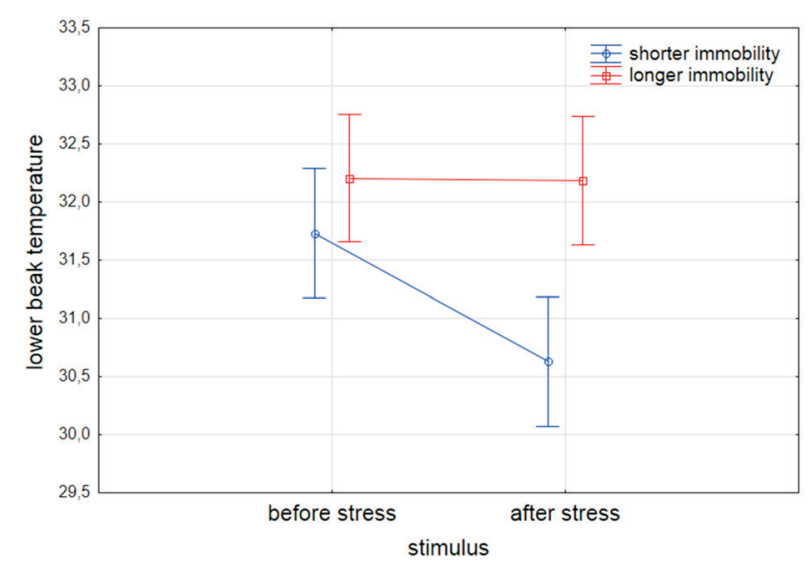

Fig. 2. Temperature of the lower beak before and after stress stimulus, including the tonic immobility division based on the median time of immobility (329 seconds) a significant interaction effect

For the upper beak, the mean temperature before TI (31.96) was significantly higher $(\mathrm{P}<0.001)$ than that after TI (31.40). Also, birds with a shorter TI time had a significantly lower $(\mathrm{P}=0.002)$ mean beak temperature (31.16) than those with a longer TI time (32.20). In addition, the interaction between stimulus and TI time was statistically significant $(\mathrm{P}=0.009)$. Like for the lower beak, birds with a shorter TI time had a significantly higher $(\mathrm{P}<0.001)$ mean beak temperature before TI (31.71) than after TI (30.60). The remaining effects for the lower or upper beak were not statistically significant (Fig. 3).

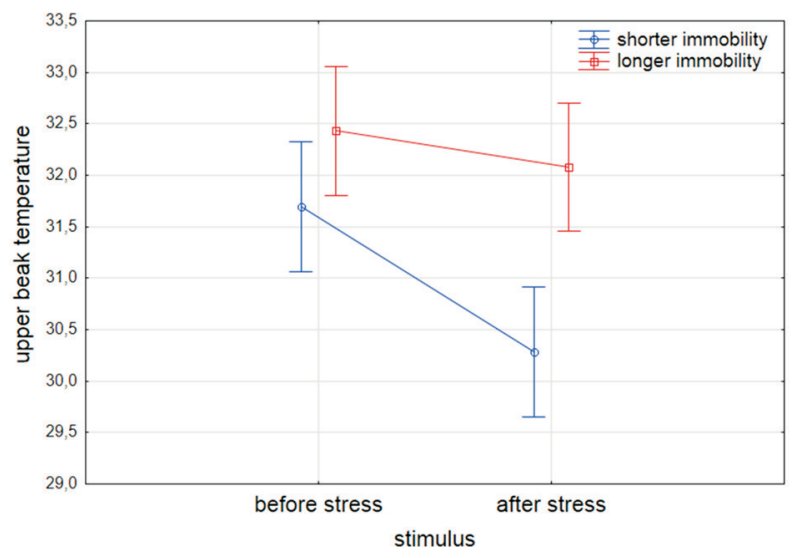

Fig. 3. Temperature of the upper beak before and after stress stimulus, including tonic immobility division based on the median time of immobility (329 seconds) a significant interaction effect

\section{Discussion}

The present study investigated the effect of TIinduced stress reaction on beak surface temperature changes using IRT. What we found was that lower and upper beak temperature was significantly higher before TI test. Previous studies on detection of stress in hens measured eye, comb and bare face with IRT as the areas highly sensitive to stress. Non however, has evaluated beak temperature changes. The temperatures of comb, face, and eye area dropped initially in response to the handling treatment, then soared to temperatures higher than baseline in the duration of stress for 20 minutes (EDGAR et al., 2013). HERBORN et al. (2015) found an initial decrease in comb and wattle temperature, followed by a larger rise compared to the basal temperature level. In the present study, birds with shorter TI had lower beak temperature than birds with longer TI. A similar temperature trend was presented by EDGAR et al. (2013), where eye temperature decreased in response to stress just after the stress, reaching a minimum of $0.8{ }^{\circ} \mathrm{C}$ within the first 3 minutes and then increased significantly after 10 minutes of handling. However, based on the previous studies on head temperature changes, where eye, comb, wattle and face area, showed an increased surface temperature in response to stress (EDGAR et al., 2013; MOE et al., 2017), in our study the upper and lower beak temperature showed a drop of temperature in response to stress. However, looking at the interaction between the time of TI and stimulus, birds with shorter TI time, had higher upper and lower beak temperature before TI. These differences were not found for hens that had longer TI time. The significant interaction between the time of TI and stimulus may be explained by the curvilinear relationship between the beak surface temperature and the time of TI. Initially, the beak surface temperature decreased with an increasing TI duration, then it reached the lowest point and, after that, it started increasing. Due to the different TI duration for birds, the beak surface temperature could have been measured either at the declining part of the curve (shorter TI duration) or already at its inclining part (longer TI duration). In other words, the beak surface temperature was observed at the different time points of the same curve 
reflecting the relationship between the temperature and TI time.

There are several studies that indicated different stressful responses between lines. The study presented by ALBENTOSA et at. (2003) found that white line presented longer TI time compared to other lines. Longer durations of TI in white line compared with brown birds confirmed the previous reports where White Leghorns showed the strong fear of human beings (MURPHY and WOOD-GUSH, 1978). In our previous study there was a correlation between the duration of TI and the TI-induced temperature changes of the surface eye temperature for white hens. In addition, white hens had higher temperatures on the right side of the head, suggesting a greater reaction to TI than brown hens (SOROKO and ZABORSKI 2020). Our study did not indicate any influence of TI time on beak temperature changes between white and brown lines. Interestingly, the current study found that brown hens had the higher temperature of the lower beak in comparison with white line. A study on a larger group would have to be done to confirm that temperature difference.

The major limitation of our study was the lack of baseline temperature. The peripheral vasoconstriction due to stress from handling and/or being taken out of their pen may have affected beak surface temperatures. CABANAC and AIZAWA (2000) found that gentle handling caused increases in core body temperature and heart rate but decreases in skin temperatures. Peripheral vasoconstriction, as measured by decreased skin temperatures, only lasted for about 6 minutes. According to EDGAR et al. (2013), comb temperature decreased significantly in response to stress, showing a rapid 2 ${ }^{\circ} \mathrm{C}$ drop. Then, the eye temperature showed a rapid $0.8{ }^{\circ} \mathrm{C}$ increase. After 10 minutes, eye and comb temperature returned to the baseline.

\section{Conclusions}

The present study is the first to demonstrate beak temperature changes in response to stress in laying hens assessed by IRT. Birds before TI test had significantly higher beak temperature then after TI test. Birds which presented shorter TI, had lower temperature of the beak than birds with longer TI. The upper and lower beak temperatures significantly decreased in response to TI test in birds with shorter TI. In addition, hens of brown line had higher lower beak temperature compared to white line hens. These results suggest that IRT could be used as a non-invasive technique to assess beak temperature changes in response to stress. IRT could greatly improve ability to evaluate hens under potentially stressful conditions.

\section{Acknowledgments}

We would like to thank the staff and graduate students of the Livestock Behavior Research Unit, USDA-ARS and the Department of Animal Sciences at Purdue University. Author Maria Soroko was supported by Fulbright Scholarship (Fulbright Senior Award) to conduct thermographic examination on birds at Purdue University. Rest of the research on poultry was supported by the USDA National Institute of Food and Agriculture, Foundation program of the Agriculture and Food Research Initiative Competitive Grants Program under the Award No: 2017-67015-26567.

\section{References}

ALBENTOSA, M. J., J. B. KJAER, C. J. NICOL (2003): Strain and age differences in behaviour, fear response and pecking tendency in laying hens. Br. Poult. Sci. 44, 333-344.

DOI: 10.1080/00071660310001598085.

BEUVING, G., G. M. VONDER (1981): The influence of ovulation and oviposition on corticosterone levels in the plasma of laying hens. Gen. Comp. Endocrinol. 44, 382388.

DOI: 10.1016/0016-6480(81)90016-2.

BOISSY, A., G. MANTEUFFEL, M. B. JENSEN, R. O. MOE, B. SPRUIJT, L. J. KEELING, C. WINCKLER, B. FORKMAN, I. DIMITROV, J. LANGBEIN, M. BAKKEN, I. VEISSIER, A. AUBERT (2007): Assessment of positive emotions in animals to improve their welfare. Physiol. Behav. 92, 375-397.

DOI: 10.1016/j.physbeh.2007.02.003

BREWARD, J., M. J. GENTLE (1985): Neuroma formation and abnormal afferent nerve discharges after partial beak amputation (beak trimming) in poultry. Experientia 41, 1132-1134.

DOI: $10.1007 / \mathrm{BF} 01951693$.

BRIESE, E., HAN HUI-WAN, M. A. PARADA (1991): Stress hyperthermia in mice. J. Therm. Biol. 16, 333-336. DOI: 10.1016/0306-4565(91)90059-B.

CAMPO, J. L., S. G. DAVILA (2002): Influence of mating ratio and group size on indicators of fearfulness and stress of hens and cocks. Poult. Sci. J. 81, 1099-1103.

DOI: $10.1093 / \mathrm{ps} / 81.8 .1099$. 
CABANAC, M, S. AIZAWA (2000): Fever and tachycardia in a bird (Gallus domesticus) after simple handling. Physiol. Behav. 69, 541-545.

DOI: 10.1016/s0031-9384(00)00227-4.

CHENG, H. W., W. M. MUIR (2007): Mechanisms of aggression and production in chickens: genetic variations in the functions of serotonin, catecholamine, and corticosterone. World Poultry Sci. J. 63, 233-254.

DOI: $10.1017 / \mathrm{S} 0043933907001432$.

DE HAAS, E. N., B. KEMP, J. E. BOLHUIS, T. GROOTHUIS, T. B. RODENBURG (2013): Fear, stress, and feather pecking in commercial white and brown laying hen parent-stock flocks and their relationships with production parameters. Poult. Sci. J. 92, 2259-2269.

DOI: $10.3382 /$ ps.2012-02996.

EDGAR, J. L., C. J. NICOL, C. A. PUGH, E. S. PAUL (2013): Surface temperature changes in response to handling in domestic chickens. Physiol. Behav. 119, 195-200.

DOI: 10.1016/j.physbeh.2013.06.020.

EL-LETHEY, H., V. AERNI, T. W. JUNGI, B. WECHSLER (2000): Stress and feather pecking in laying hens in relation to housing conditions. Br. Poult. Sci. 41, 22-28. DOI: $10.1080 / 00071660086358$.

FAIRHURST, G. D., T. A. MARCHANT, C. SOOS, K. L. MACHIN, R. G. CLARK (2013): Experimental relationships between levels of corticosterone in plasma and feathers in a free-living bird. J. Exp. Biol. 216, 4071-4081. DOI: $10.1242 /$ jeb.091280.

FIELD, A. (2009): Discovering Statistics Using SPSS. $3^{\text {rd }}$ ed., Sage Publications Ltd., London.

FRAISSE, F., J. F. COCKREM (2006): Corticosterone and fear behaviour in white and brown caged laying hens. Br. Poult. Sci. 47, 110-119.

DOI: $10.1080 / 00071660600610534$.

GYIMOTHY, I. (2004): Stress factors and stress responses in poultry breeding. Literature review. Magy. Allatorv. Lapja 126, 101-106.

HERBORN, K. A., J. L. GRAVES, P. JEREM, N. P. EVANS, R. NAGER, D. J. MCCAFFERTY, D. E. F. MCKEEGAN (2015): Skin temperature reveals the intensity of acute stress. Physiol. Behav. 152, 225-230.

DOI: 10.1016/j.physbeh.2015.09.032.

HEMSWORTH, P. H., G. J. COLEMAN, J. L. BARNETT, R. B. JONES (1994): Behavioural responses to humans and the productivity of commercial broiler chickens. Appl. Anim. Behav. Sci. 41, 101-114.

DOI: 10.1016/0168-1591(94)90055-8.

JONES, R. B., J. M. FAURE (1981): Sex and strain comparisons of tonic immobility (Righting time) in the domestic fowl and the effects of various methods of induction. Behav. Process. 6, 47-55.

DOI: $10.1016 / 0376-6357(81) 90015-2$.
KORTE, S. M., G. BEUVING, W. RUESINK, H. J. BLOKHUIS (1997): Plasma catecholamine and corticosterone levels during manual restraint in chicks from a high and low feather pecking line of laying hens. Physiol. Behav.; 62, 437-441.

DOI: 10.1016/S0031-9384(97)00149-2.

KUENZEL, W. J. (2007): Neurobiological Basis of Sensory pereception: welfare implications of beak trimming. Poult. Sci. J. 86, 1273-1282.

DOI: $10.1093 / \mathrm{ps} / 86.6 .1273$.

MOBERG, G. P. (2000): Biological response to stress: implications for animal welfare. In: The Biology of Animal Stress: $1^{\text {st }}$ ed. Basic Principles and Implications for Animal Welfare (Moberg, G. P., J. A. Mench Eds.), CABI International, Wallingford, UK; pp. 2.

MOE, R. O., J. BOHLIN, A. FLØ, G. VASDAL, S. M. STUBSJØEN (2017): Hot chicks, cold feet. Physiol. Behav. 179: 42-48.

DOI: 10.1016/j.physbeh.2017.05.025.

MURPHY, L. B., D. G. M. WOOD-GUSH (1978): The interpretation of the behaviour of the domestic fowl in strange environments. Physiol. Behav. 3, 39-61.

SOROKO M., K. HOWELL, A. ZWYRZYKOWSKA, K. DUDEK, P. ZIELIŃSKA, R. KUPCZYŃSKI (2016): Maximum eye temperature in the assessment of training in racehorses: correlations with salivary cortisol concentration, rectal temperature and heart rate. J. Equine Vet. Sci. 45, 39-45.

DOI: $10.1016 /$ j.jevs.2016.06.005

SOROKO, M., D. ZABORSKI (2020): Investigation of the effects of probiotic, Bacillus subtilis on stress reactions in laying hens using infrared thermography. PLoS ONE, PLoS ONE 15, e0234117.

DOI: 10.1371/journal.pone.0234117.

STEWART, M., K. J. STAFFORD, S. K. DOWLING, A. L. SCHAEFER, J. R. WEBSTER (2008): Eye temperature and heart rate variability of calves disbudded with or without local anaesthetic. Physiol. Behav. 93, 789-797.

DOI: 10.1016/j.physbeh.2007.11.044.

SYMONDS, M. R. E., G. J. TATTERSALL (2010): Geographical variation in bill size across bird species provides evidence for Allen's rule. Am. Nat. 176, 188-197. DOI: $10.1086 / 653666$.

TATTERSALL, G. J. (2016): Infrared thermography: A noninvasive window into thermal physiology. Comp. Biochem. Physiol., Part A Mol. Integr. Physiol. 202, 78-98. DOI: 10.1016/j.cbpa.2016.02.022.

WEIMER, S. L. (2017): Noninvasive measures of stress and lameness in broilers. Phd, University of Arkansas, Fayetteville, US.

WESCHENFELDER, A. V., S. TORREY, N. DEVILLERS, T. CROWE, A. BASSOLS. Y. SACO, M. PIÑEIRO, L. SAUCIER, L. FAUCITANO (2012): Effects of trailer 
design on animal welfare parameters and carcass and meat quality of three Pietrain crosses being transported over a short distance. J. Anim. Sci 2012; 90, 3220-3231.

DOI: $10.2527 /$ jas.2012-4676
VAN DE VEN, T. M. F. N., R. O. MARTIN, T. J. F. VINK, A. E. MCKECHNIE, S. J. CUNNINGHAM (2016): Regulation of heat exchange across the hornbill beak: functional similarities with toucans? PLoS ONE, 11, e0154768.

DOI: 10.1371 journal.pone. 0154768

Received: 29 May 2020

Accepted: 25 November 2020

SOROKO, M., D. ZABORSKI: Infracrvena termografija za mjerenje promjena temperature kljuna kao odgovor na akutni stres u kokoši nesilica. Vet. arhiv 91, 647-654, 2021.

\section{SAŽETAK}

Cilj ovog rada bio je istražiti promjene temperature površine kljuna u kokoši nesilica uzrokovane stresom zbog straha pri testu tonične imobilnosti. Mjerenja su obavljena infracrvenom termografi-jom. Istraženo je i razlikuje li se temperatura kljuna u smeđe i bijele linije. Uključeno je 89 kokoši obiju linija: 45 jedinki pasmine White Leghorn i 44 smeđe jedinke pasmine Hy-Line. Temperatura kljuna mjerena je infracrvenom termografijom neposredno prije te poslije testa tonične imobilnosti. Prosječna temperatura dobivena je mjerenjem gornjeg i donjeg dijela kljuna. Temperatura kljuna prije testa tonične imobilnosti bila je znakovito viša nego poslije testa tonične imobilnosti. Jedinke s kraćom toničnom imobilnošću imale su nižu temperaturu kljuna od ptica u kojih je tonična imo-bilnost dulje trajala. Interakcija podražajnog učinka (prije i poslije tonične imobilnosti) i vrijeme tonične imobilnosti bili su znakoviti. Temperatura gornjeg i donjeg dijela kljuna znakovito je snižena $(\mathrm{P}<0,001)$ kao odgovor na test tonične imobilnosti u jedinki u kojih je test kraće trajao. Smeđe jedinke imale su višu temperaturu donjeg dijela kljuna u usporedbi s jedinkama bijele linije. Na temelju ovih rezultata, u kokoši u kojih je učinjen test tonične imobilnosti došlo je do promjene temperature površine kljuna koja je izmjerena termografijom. Infracrvena termografija mogla bi se stoga upotrijebiti kao neinvazivna metoda procjene temperaturnih promjena koje prate odgovor na stres. Navedeno bi moglo unaprijediti mogućnost procjene kokoši koje su izložene potencijalno stresnim uvjetima.

Ključne riječi: infracrvena termografija; temperatura kljuna; tonična imobilnost; odgovor na stres; kokoši nesilice 